\title{
Determinants of Strawberry Production in Beheira Governorate and Post-Harvest Treatments according to International Quality Standards
}

Doaa H. I. Mahmoud ${ }^{1}$ and Fayrouz A. A. Ahmed ${ }^{2}$

${ }^{1}$ Department of Economics and Agribusiness, Faculty of Agriculture, Alexandria University

${ }^{2}$ Department of Economics and Agricultural Extension and Rural Development, Faculty of Agriculture, Damanhour University

$$
\begin{aligned}
& \text { دحددات إنتاج الفراولة بمحافظة البحيرة ومعاملات ما بعد الحصاد وفقاً لمعايير الجودة العالمية }
\end{aligned}
$$

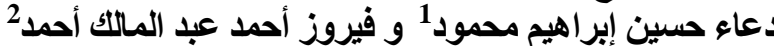

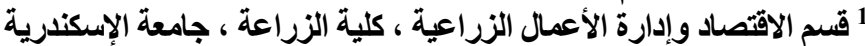

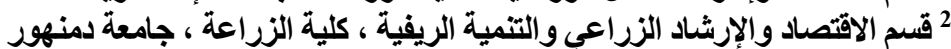<smiles>[AsH2]</smiles>

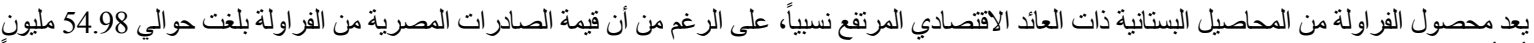

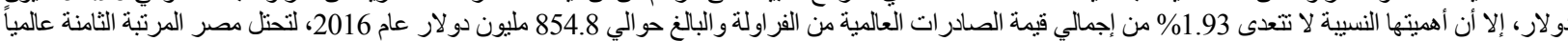

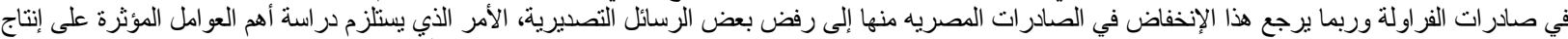

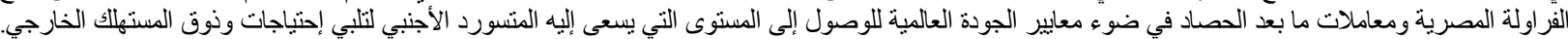

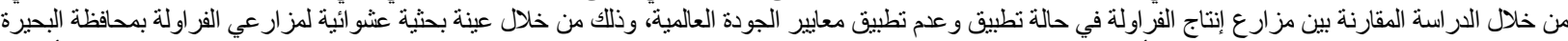

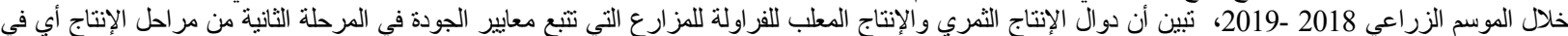

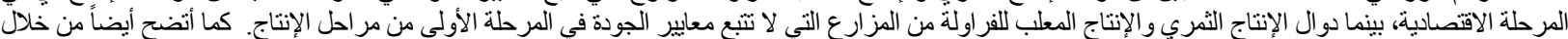

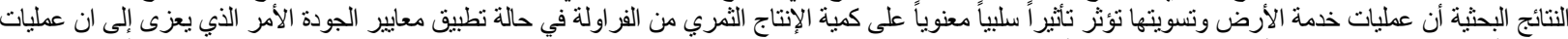

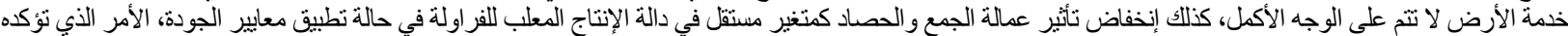

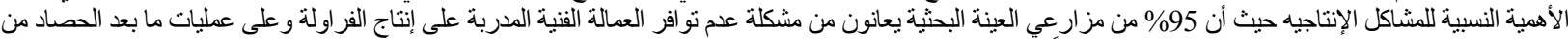

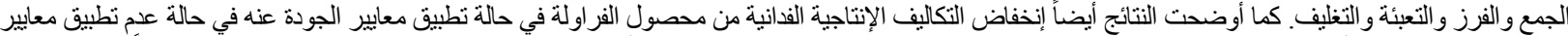

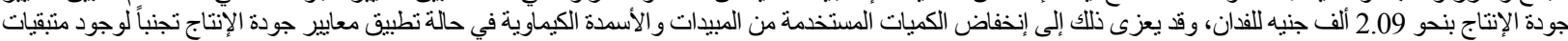

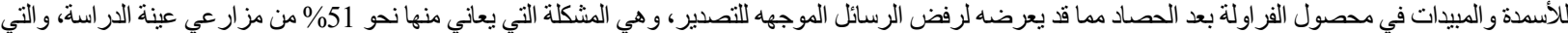

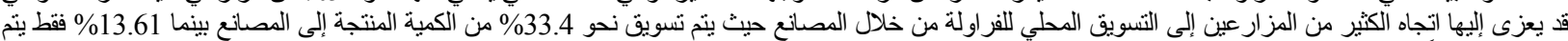

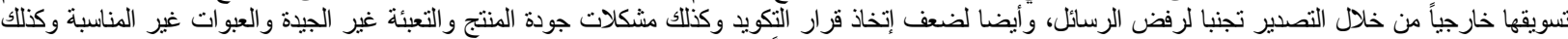

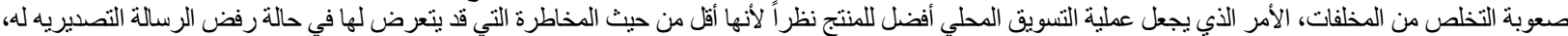

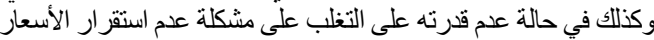

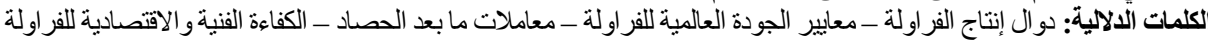

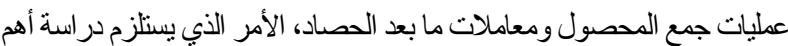

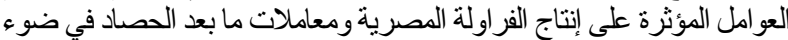

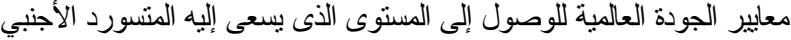
التلبي إحتياجات وذوق المستهايك الخارجي. لإسي.

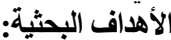

بيتهف البحث بصفة رئيسية دراسة محددات إنتاج الفراولة ومعاملات

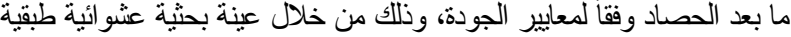

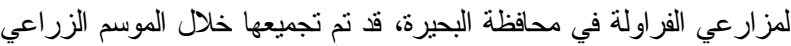

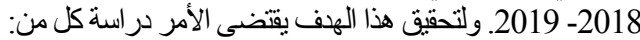

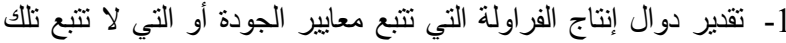

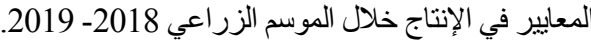

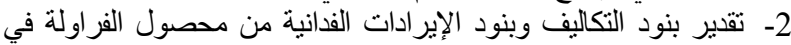

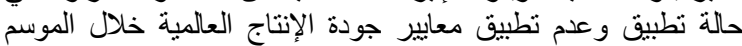

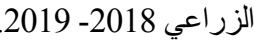
3- تحليل الكفاءة الفنبة والاقتصادية للفدان من محصول الفراولة باستخدام بعض المؤشرات الاقتصادية. 4- التعرف على أهم الشكلات التهانية التي نواجه عملية إنتاج الفراولة ووضع توصيات للحلول المقترحة لها.

\section{الطريقة البحثية}

اعتمد البحث على كل من التحليل الاقتصادي الوصفي والقئل القياسي

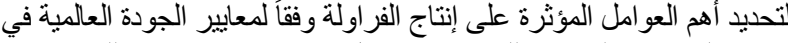

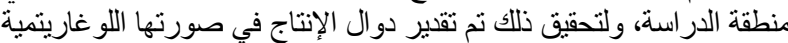

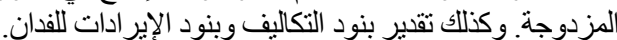

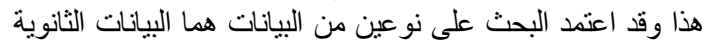

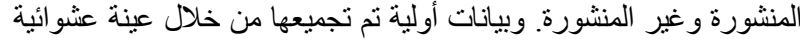

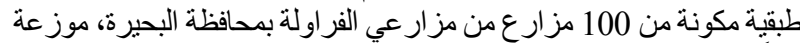

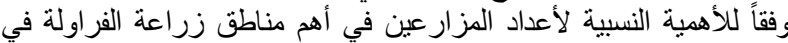

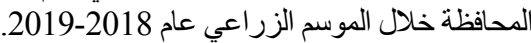

\section{المقدمة}

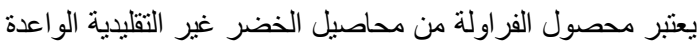

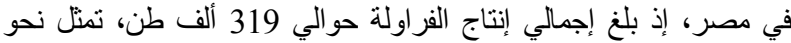

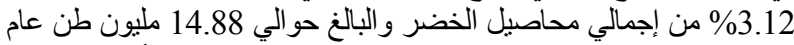

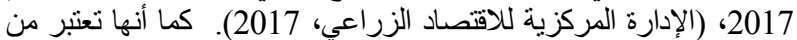

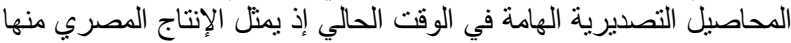

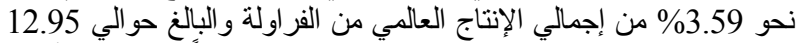

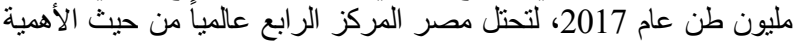
النسبية لكمية الإنتاج. (منظمة الفاو، 2017، 2017).

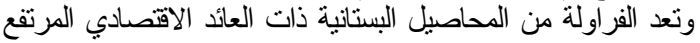

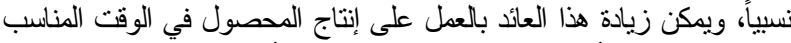

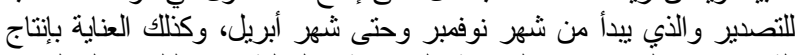

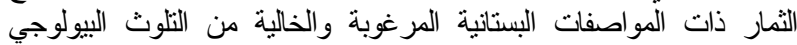

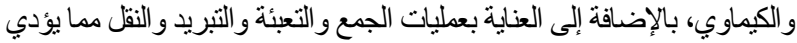

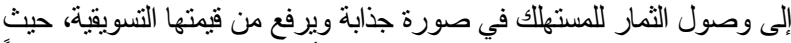

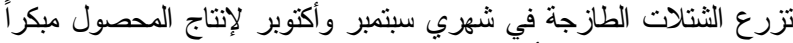

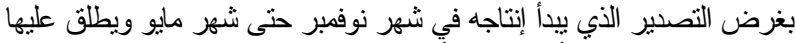

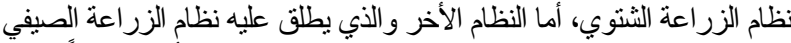

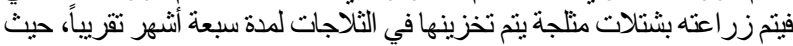

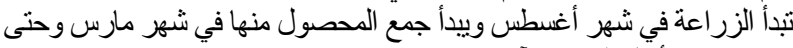
شهر يونيو. (أمال الثيمي وآخرون، 2006). المشكلة البحثية:

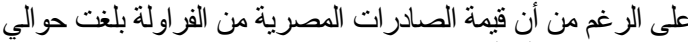

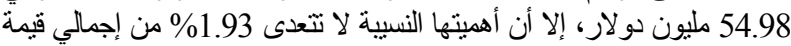

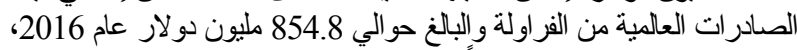

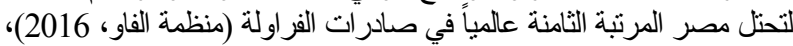

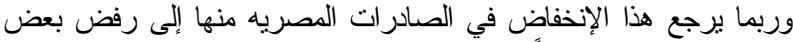

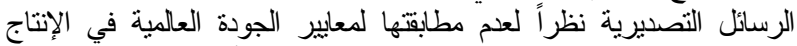

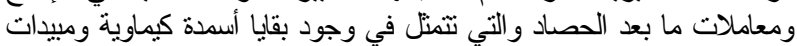

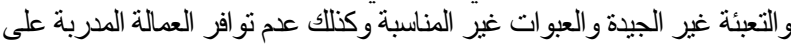




\section{Doaa H. I. Mahmoud and Fayrouz A. A. Ahmed}

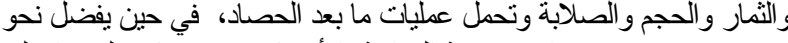

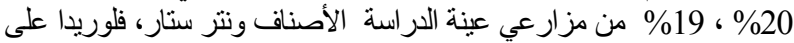

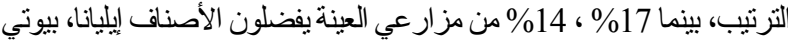
على التزتيب.

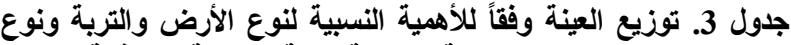

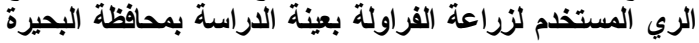

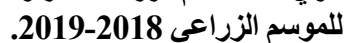

\begin{tabular}{|c|c|c|}
\hline$\%$ & التكرار & البيان \\
\hline & & ع الأرض: \\
\hline 12 & 12 & أر اضي قديمة \\
\hline 88 & 88 & أر اضي جديدة \\
\hline & & نوع التربة: \\
\hline 88 & 88 & \\
\hline 12 & 12 & طينية \\
\hline 100 & 100 & تققيط \\
\hline - & - & رش ش \\
\hline - & - & \\
\hline
\end{tabular}

جدول 4. توزيع العينة وفقاً للأهمية النسبية لأصناف الفراولة التي يفضية التضلها

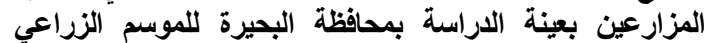

2019-2018

\begin{tabular}{|c|c|c|}
\hline$\%$ & التكرار & صنف الفراولة \\
\hline 58 & 58 & ليرتونا \\
\hline 56 & 56 & ئيستيفال \\
\hline 19 & 19 & فلوريدا \\
\hline 17 & 17 & يانا \\
\hline 20 & 20 & تز ستار \\
\hline 14 & 14 & تىى \\
\hline
\end{tabular}

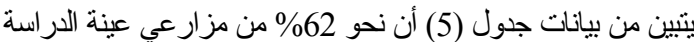

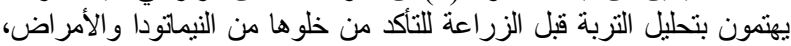

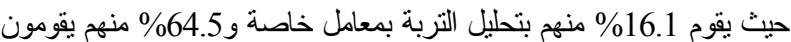

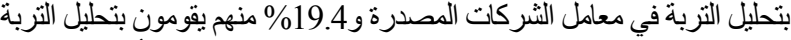

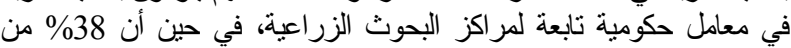

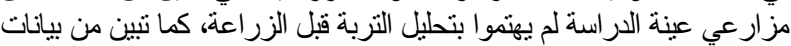

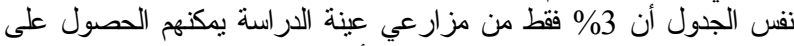

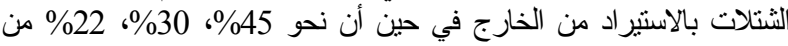
مزارعي عينة الدراسة يحصلون على الثئل الثتلات من المشاتل الخاصة، الثركات

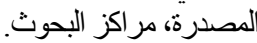

جدول 5. توزيع العينة وفقاً للأهمية النسبية لإهتمام المزارعين بتحليل التربة

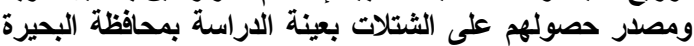

\begin{tabular}{|c|c|c|}
\hline \multirow[b]{2}{*}{$\%$} & \multicolumn{2}{|c|}{ للموسم الزراعي 2018-2019. } \\
\hline & 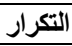 & البيان \\
\hline \multicolumn{3}{|r|}{ نحليل التربة قبل الزر اعة: } \\
\hline 62 & 62 & نعم \\
\hline 38 & 38 & y \\
\hline \multicolumn{3}{|r|}{ الجهة المسؤولة عن التحليل: } \\
\hline 16.1 & 10 & معمل خاص \\
\hline 64.5 & 40 & الثركات المصدرة \\
\hline 19.4 & 12 & معمل حكومي (تابع للبحوث الزر اعية) \\
\hline \multicolumn{3}{|r|}{ جهات الحصول على الثتنلات: } \\
\hline 3 & 3 & 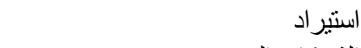 \\
\hline 30 & 30 & الثركات المصدرة \\
\hline 45 & 45 & المشاتل الخاصة \\
\hline 22 & 22 & مر اكز البحوث \\
\hline
\end{tabular}

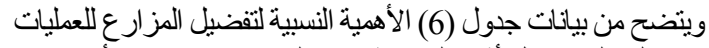

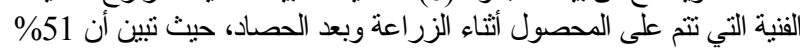

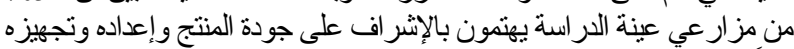

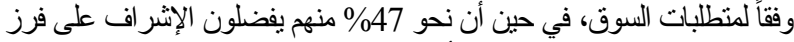

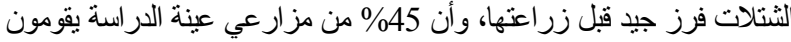

توصيف العينة البحثة:

تعتبر محافظة البحيرة من أكبر المحافظات الزر اعية في مصر ، كما أنها

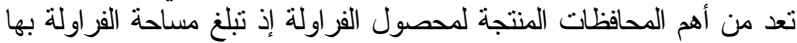

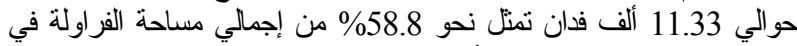

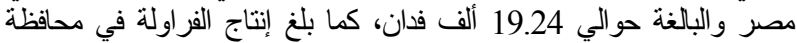

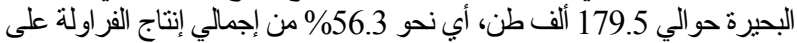

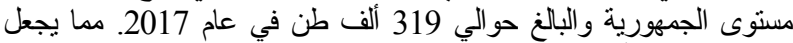

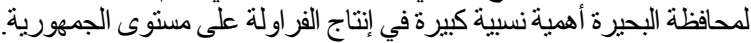

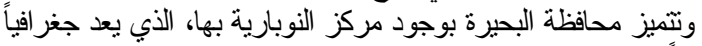

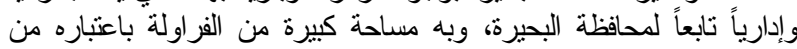

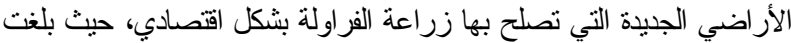

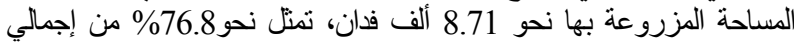

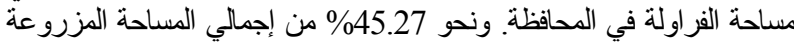
على مستوى الجمهورية. وقد وجد أن زراعة الفراولة بها نتركز في مركزي كوم حماده

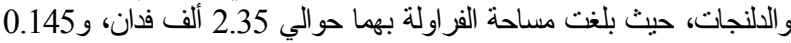

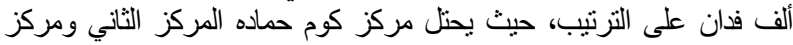

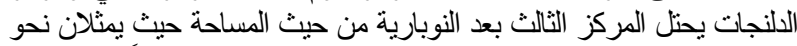

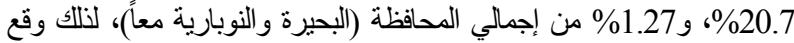
الإختيار على هذين المركزين لاختيار العينة منهما دون الإلتفات إلى بالقي لإلى

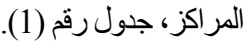

جلول 1. المساحة المزروعة من الفراولة بمراكز محافظة البحيرة، عام 2018 المبرة

\begin{tabular}{|c|c|c|}
\hline الأهمية النسبية \% & المساحة (فذان) & المركز \\
\hline 76.8 & 8709 & النوبارية \\
\hline 20.7 & 2350 & حمادة \\
\hline 1.27 & 145 & 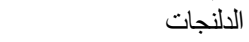 \\
\hline 0.88 & 100 & ـ النطرون \\
\hline 0.22 & 25 & كليس \\
\hline 100 & 11329 & مالي البحيرة و النوبارية \\
\hline
\end{tabular}
بيانات حصر الفراولة بنواحي المحافظة، بياتات غير منشورة، الخئ، 2018.

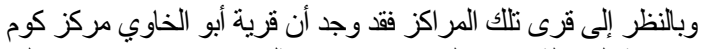

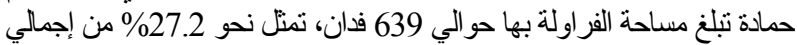

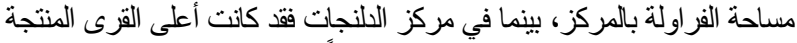

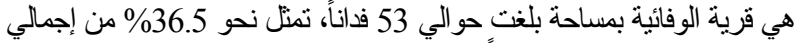

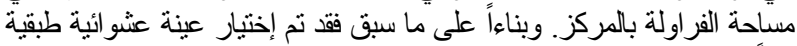

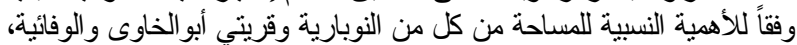

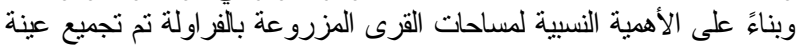

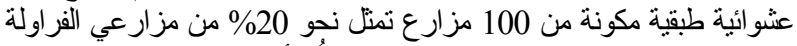

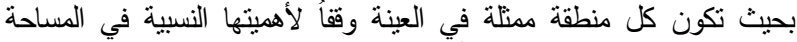

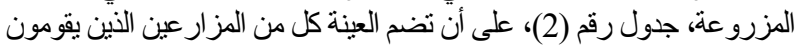

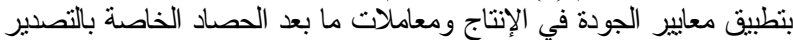
وكنلك المزار عين الذين لا يقومون بنطبيق تلاك المعايير.

جدول 2. عدد المزارعين الكلي للفراولة وأعداد مزارعي العينة البحثية في لئي منطقة الاراسة خلال الموسم الزراعي 2018- 2019.

\begin{tabular}{|c|c|c|c|}
\hline الأهمية & علد مزارعي & لمزارعي الفراولة العدلي & \\
\hline$\% 19.8$ & 69 & 347 & \\
\hline$\% 20.3$ & 26 & 128 & أبو الخاوي (مركز كوم حماده) \\
\hline$\% 20$ & 5 & 25 & ة الوفائية (مركز الدلنجات) \\
\hline$\% 20$ & 100 & 500 & جيمالي \\
\hline
\end{tabular}
بياتات حصر الفراولة بنواحي المحَفظة، بياتات غير منشورة، 2018.

خصائص وسمات العينة البحثية:

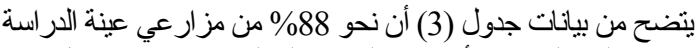

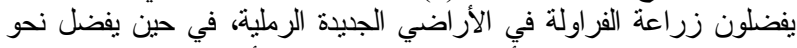

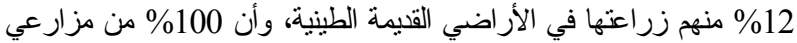

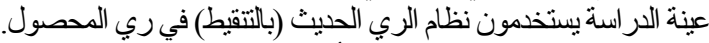

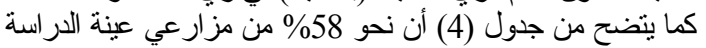

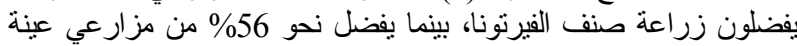

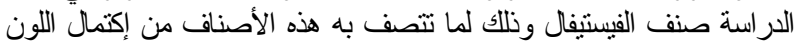




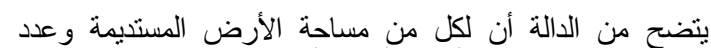

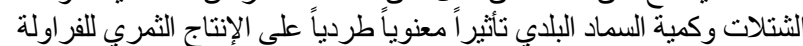

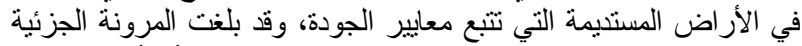
لتالك المتغير الات

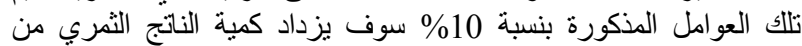

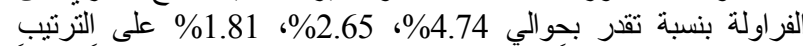

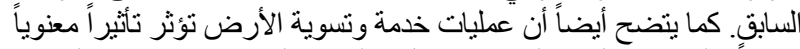

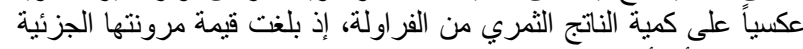

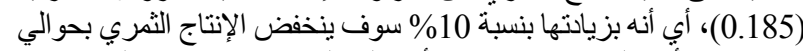

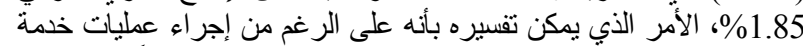

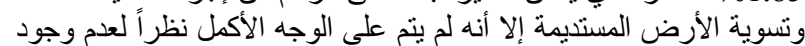

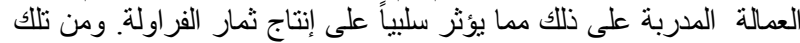

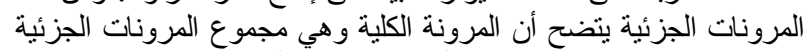

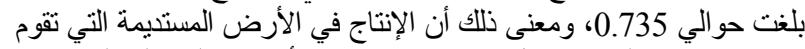

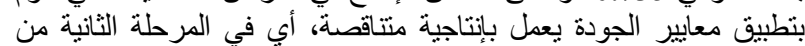

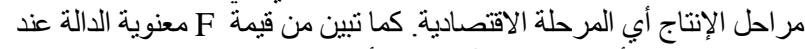

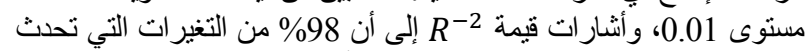

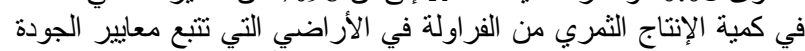

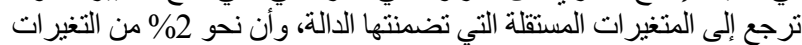
التي تحدث في الكبيه الناتجة منه ترجع إلى التى العو امل الأخرى.

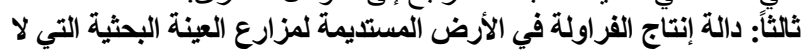
تلتبع معايير الجودة في الإنتاج:

تبين من إجراء التقدير القياسي لأهم العوامل المؤثرة على عمليات

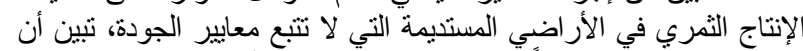

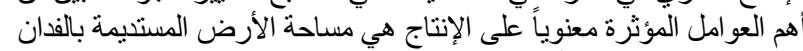

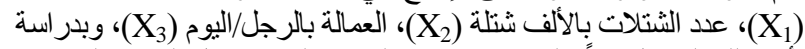

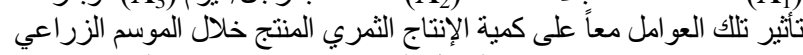

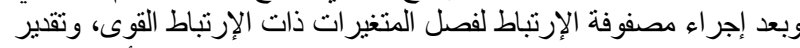
$\operatorname{Ln} Y_{3}=$

دالة الإنحدار الدتعدد باستخدام النموذج اللوغارينمي المزدوج تبين أن:

$$
\begin{aligned}
& -\operatorname{Ln} 0.27+0.523 \operatorname{Ln} X_{1}+0.405 \operatorname{Ln} X_{2}+0.105 \operatorname{Ln} X_{3}
\end{aligned}
$$

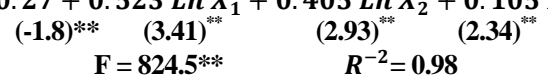

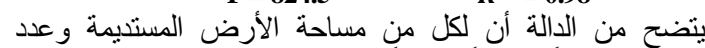

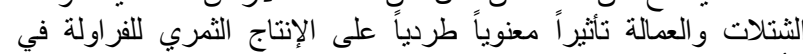

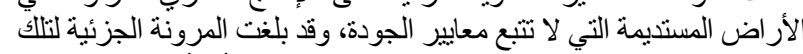

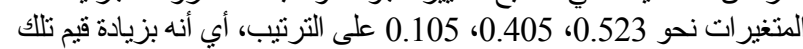

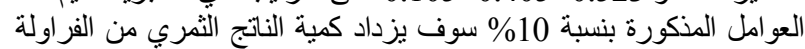

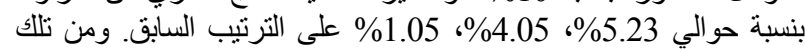

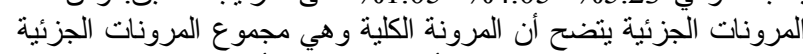

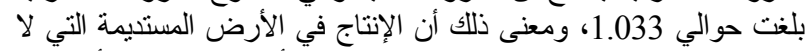

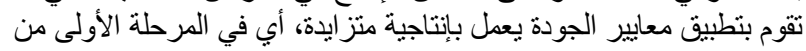

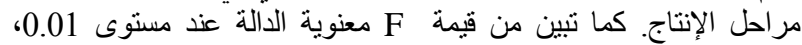

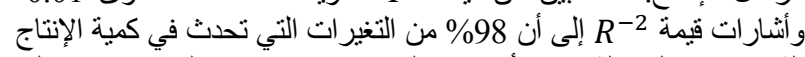

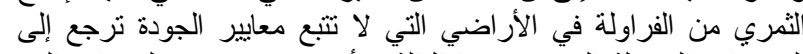

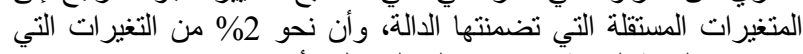

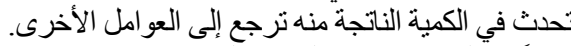

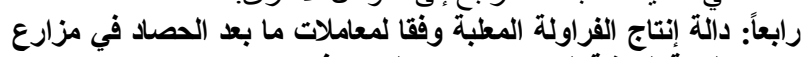
العينة البحثية التي تتبع معايير الجودة في الإتتاج:

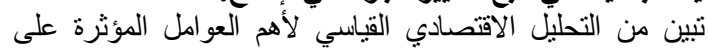

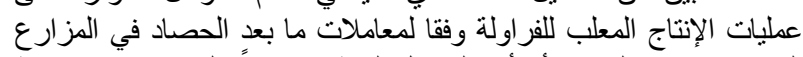

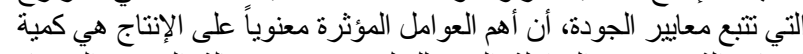

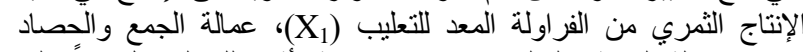

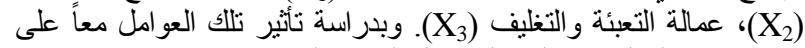

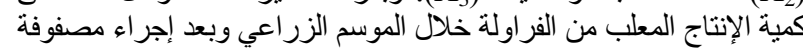

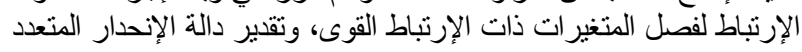

$\operatorname{Ln} Y_{4}=$

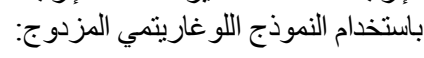

$$
\begin{aligned}
& -\operatorname{Ln} 0.027+0.88 \operatorname{Ln} X_{1}+0.038 \operatorname{Ln} X_{2}+0.014 \operatorname{Ln} X_{3} \\
& \begin{array}{cc}
(-3.43)^{* * *} \\
F=717.6^{* * *}
\end{array} \quad(1.89)^{*} \quad(2.11)^{* * *}
\end{aligned}
$$

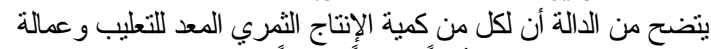

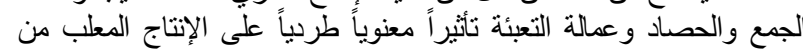

بالإثراف على برامج الري و النسميد و المكافحة، في حين أن 40\% منهم يهتمون بالإثراف على كيفيةز زراعة الثنتلات بطريقة صحيحة.

\begin{tabular}{|c|c|c|}
\hline$\%$ & 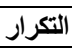 & العملية الفنية الزراعية \\
\hline 47 & 47 & الإشراف على فرز الثتلات فرز جيد قبل زر اعنها \\
\hline 40 & 40 & الإشر اف على كيفية زر اعة الثتلة بطريقة صحيحة \\
\hline 45 & 45 & الإشر اف على برامج الري و التسميد و المكافحة. \\
\hline 51 & 51 & الإنشراف على جودة المنتج و إعداده وتجهيزهوفقاً لمنطلبات السوق \\
\hline
\end{tabular}

جدول 6. توزيع العينة وفقاً للأهمية النسبية للعمليات الفنية التي تتم على التئية

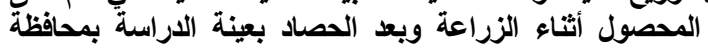
البحيرة للموسم الزراعي 2018-2019 الزئية

أهم المؤشرات الإتتاجية والاقتصادية لمزارع إنتاج الفراولة بلاعينة البحثية:

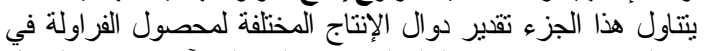

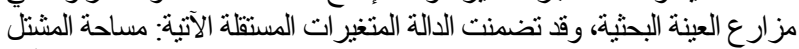

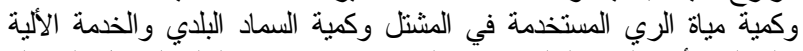

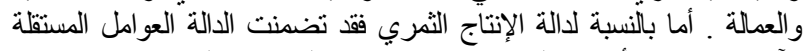

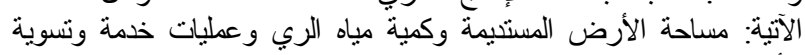

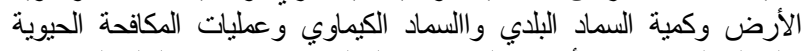

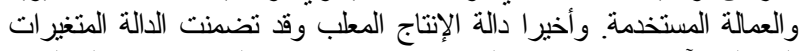

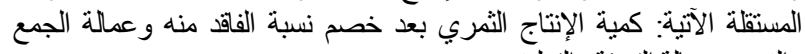
والفرز و عمالة التعبئة و التغليف.

أولاً: دالة إنتاج شتَلات الفراولة بمشاتل مزارع العينة البحثية:

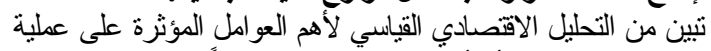

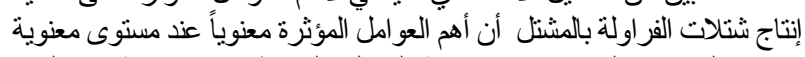

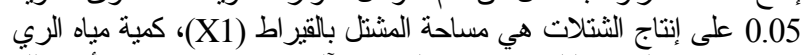

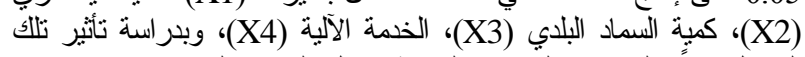

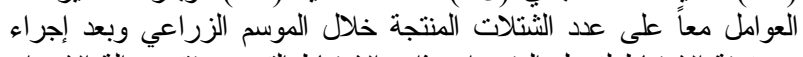

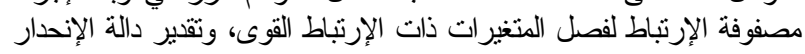
$\operatorname{Ln} Y_{1}=$

$\operatorname{Ln} Y_{1}=$
$\operatorname{Ln} 3.325$

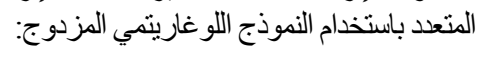
$\operatorname{Ln} 3.325+$
$(92.2)$
(92.2) $\quad(\mathbf{9 . 7 7})$
$(9.77)^{m+1}$
$(-4.45)^{\text {*** }}$
(2.76)
$R^{-2}=0.819$

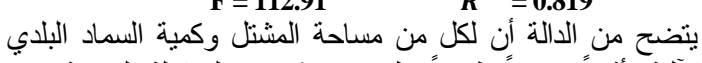

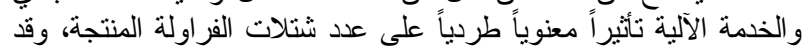

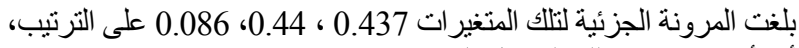

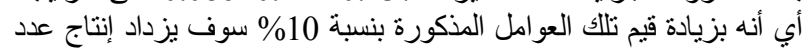

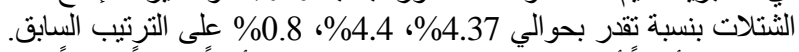

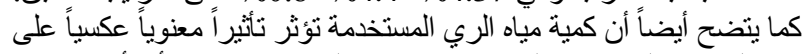

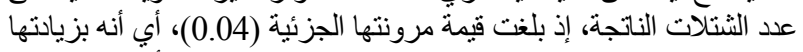

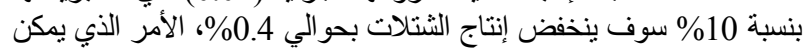

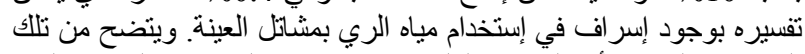

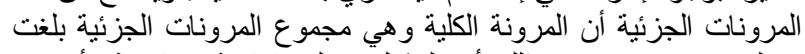

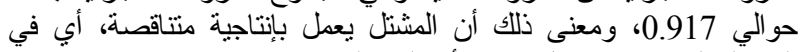

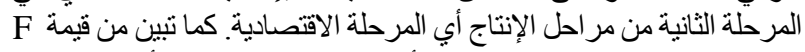

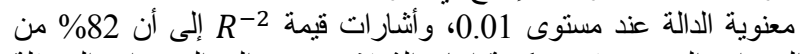

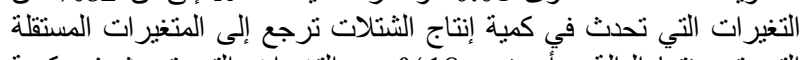

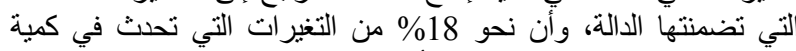

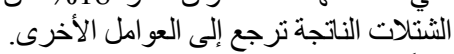

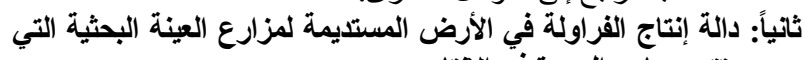
تتبع معايير الجودة في الإنتاج:

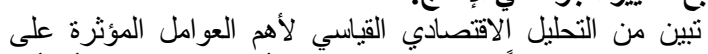

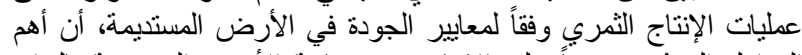

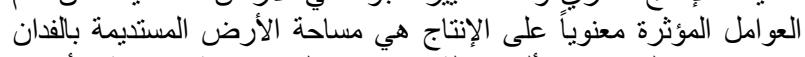

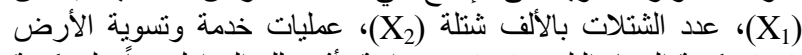

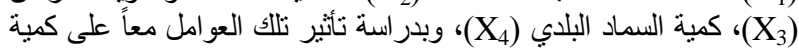

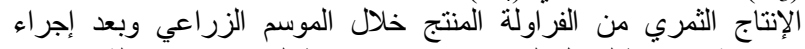

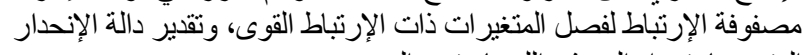
$\operatorname{Ln} Y_{2}=$

المتعدد باستخدام النموذج اللوغ غاريتمي المزدوج:

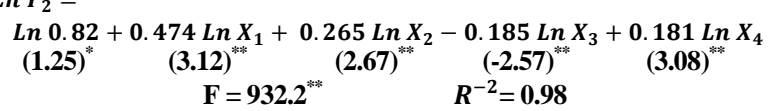


نحو 1.73\% ، 1.71\% على الترتيب، هذا وجاءت في المرتبة الأخيرة تكاليف تجهيز المشتل في حالة تطبيق و عدم تطبيق معايير جودة الإنتاج.

جدول 7. بنود تكاليف تجهيز وزراعة مشتل الفدان من الفراولة لمزارعي جئي

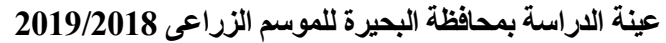

\begin{tabular}{|c|c|c|}
\hline$\%$ & التكلفة بالألف جنيه & البند \\
\hline 93.69 & 12.65 & تكلفة الشتلات \\
\hline 1.69 & 0.228 & تقليب الأرض \\
\hline 1.64 & 0.221 & تسوية الأرض \\
\hline 1.27 & 0.171 & الحرث الحرث \\
\hline 1.71 & 0.231 & الزراعة \\
\hline 100 & 13.51 & الإجمالي \\
\hline
\end{tabular}

جلول 8. بنود تكاليف تجهيز وزراعة مشتل الفدان من الفراولة في حالة

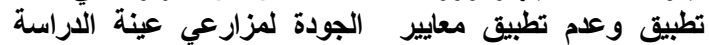

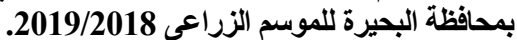

\begin{tabular}{|c|c|c|c|c|}
\hline \multicolumn{2}{|c|}{ في حالة علم تطييق معايير الجودة } & \multicolumn{2}{|c|}{ في حالة تطييق معايير الجودة } & \multirow{2}{*}{ البنذ } \\
\hline$\%$ & التكلفة بالأف جنيه & $\%$ & التكلفة بالألف جنيه & \\
\hline 93.76 & 12.55 & 93.64 & 12.74 & تكلفة الشتلات \\
\hline 1.66 & 0.222 & 1.70 & 0.232 & تقليب الأرض \\
\hline 1.69 & 0.226 & 1.58 & 0.215 & تسوية الأرض \\
\hline 1.18 & 0.158 & 1.35 & 0.183 & الحرث الحرث \\
\hline 1.71 & 0.229 & 1.73 & 0.235 & الزر اعة \\
\hline 100 & 13.391 & 100 & 13.606 & الإجمالي \\
\hline
\end{tabular}

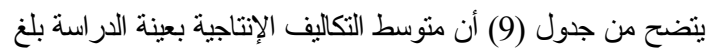

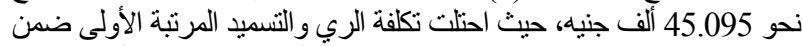

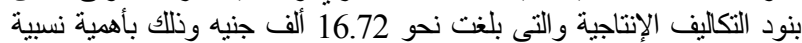

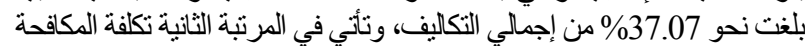

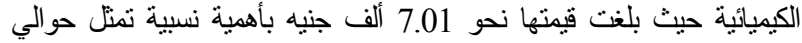

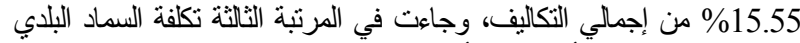

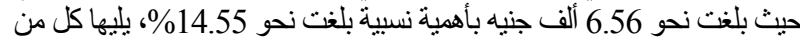

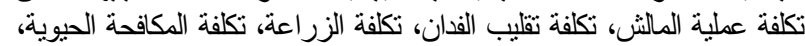

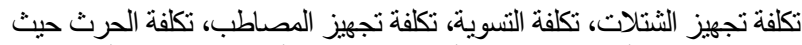
بلغت نحو 5.47 ألف جنيه، 2.99 ألف جنيه، 2.55 ألف جنيه، 2.55 ألف 1.18 ألف جنيه،

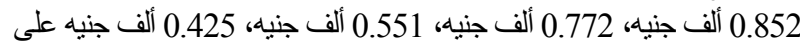

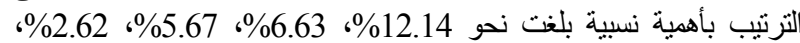

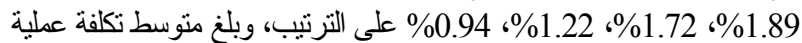

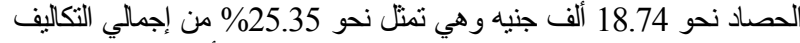

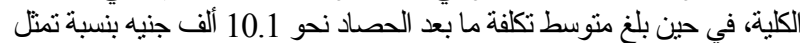
نحو 13.64\% من إجمالي التكاليف الكلية.

جدول 9. بنود 134\% تكليف إنتاج وحصاد وتكاليف ما بعد الحصاد لقدان الفراولة

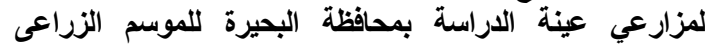

2019/2018

\begin{tabular}{|c|c|c|}
\hline$\%$ & التكلفة (ألف جنيه /فدان) & البند \\
\hline 1.89 & 0.852 & تكلفة تجهيز الثتلات \\
\hline 6.63 & 2.991 & تقليب الفدان \\
\hline 1.73 & 0.772 & تكلفة التسوية \\
\hline 0.94 & 0.425 & تكلفة الحرث \\
\hline 14.55 & 6.561 & تكلفة السماد البلدي \\
\hline 1.22 & 0.552 & تكلفة تجهيز المصتّاطب \\
\hline 5.67 & 2.556 & الزراعة \\
\hline 37.07 & 16.716 & الري والتسميد \\
\hline 2.62 & 1.183 & المكافحة الحيوية \\
\hline 15.55 & 7.012 & المكافحة الكيميائية \\
\hline 12.14 & 5.494 & تكلفة عملية المالش \\
\hline 100 & 45.095 & الإجمالي \\
\hline$* 25.25$ & 18.737 & تكلفة عملية الحصاد \\
\hline$* 13.64$ & 10.082 & تكلفة ما بعد الحصاد \\
\hline- & 73.913 & إجمالي التكاليف الكلية \\
\hline
\end{tabular}

المصدر : جمعت وحسبت من بياتات استمارات استبيان عينة الدراسة.
الفراولة الناتجة من المزارع التي تتبع معايير الجودة، وقد بلغت المرونة الجزئية

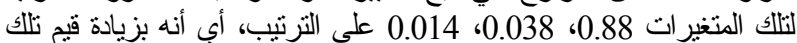

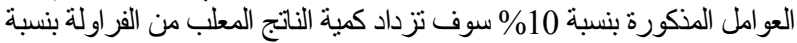

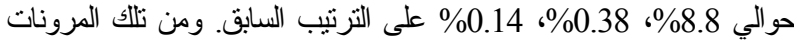

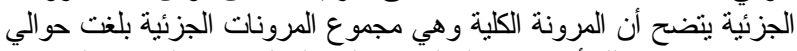

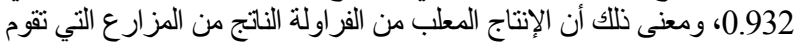

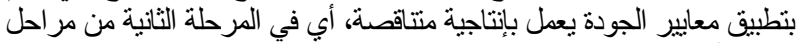

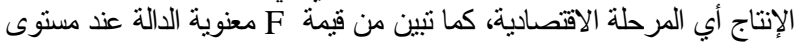

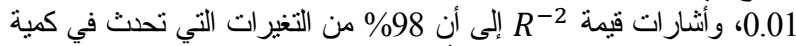

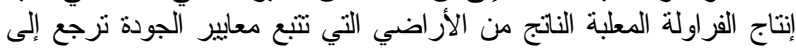

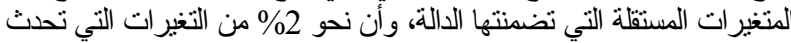

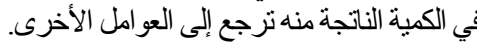

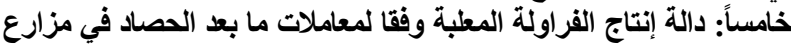

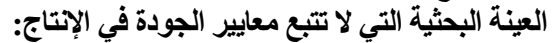

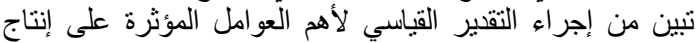

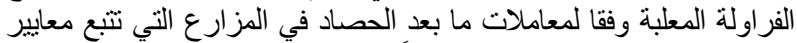

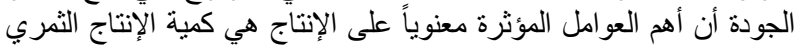

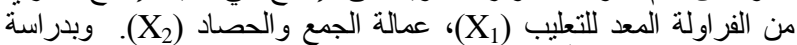

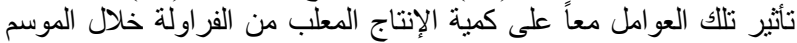

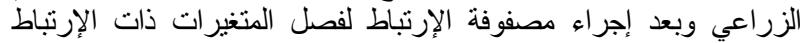
القوى، وتقدير دالة الإنحدار المتعدد باستخدام النموذج اللو غاريتمي المزدو التون $\operatorname{Ln} Y_{5}=-\operatorname{Ln} 0.17+0.91 \operatorname{Ln} X_{1}+0.62 \operatorname{Ln} X_{2}$

$$
\begin{array}{cc}
(-0.101) & (20.9)^{* * *} \\
\mathbf{F}=261.8 & R^{-2}=0.94
\end{array}
$$

يتضح من الدالة أن لكل من كمية الإنتاج الثنري المعد للتعليب و عمالة

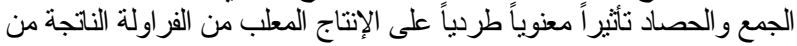

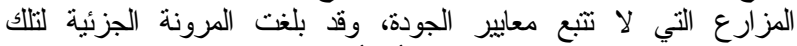

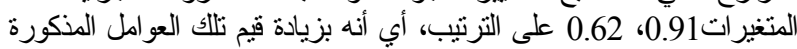

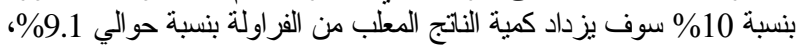

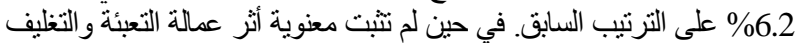

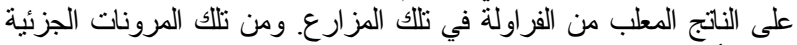

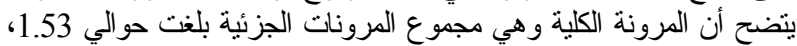

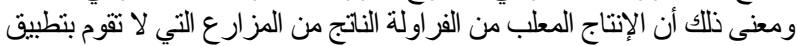

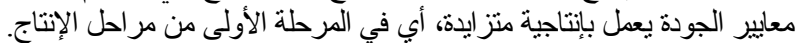

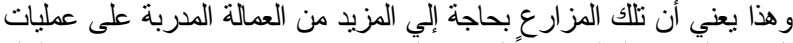

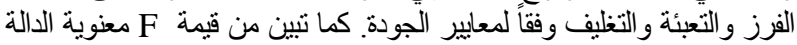

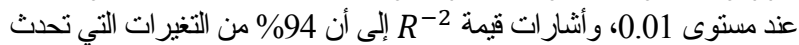

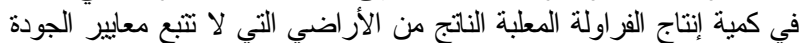

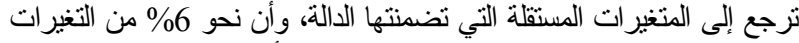

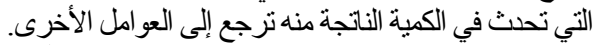

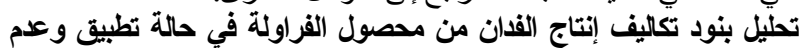

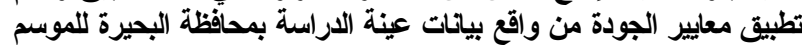
الزراعي 2018-2019. بعد العمل على دراسة تكاليف الإتتاج وتننيتها أمر اً اقتصادياً بالغ الأهية

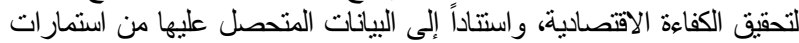

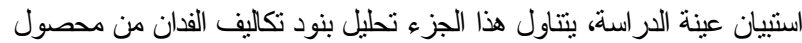

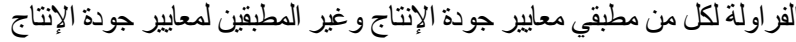
، وكنلك عرض مؤشرات الكفاءة الفنية والاقتصادية الإنتائ.

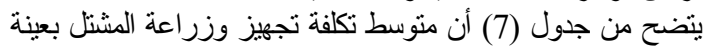

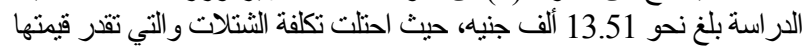
بنحو 12.65 ألف جنيه المرتبة الأولى بين بنود التكاليف بنسبة بلغت حوالي التئ

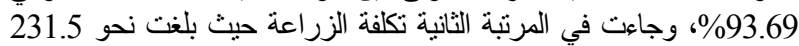

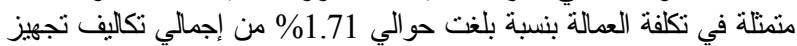

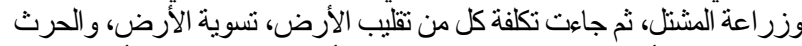

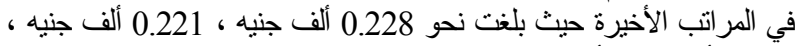
0.171 ألف جنيه بأهمية نسيية بلغت حو الي 1.69\% \% الترتيب.

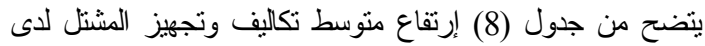

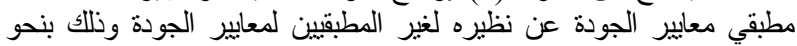

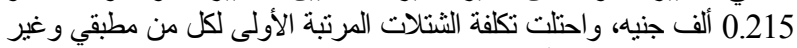

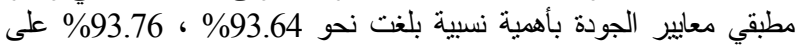
الترتيب ، بينما جاءت في المرتبة الثنانية تكلفة زر باعة الثتلات بأهمية نسبية بلغت 
المرتبة الثانية حيث يستوعب هذا السوق نحو 5.305 طناً من الفراولة

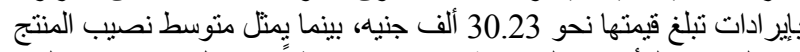

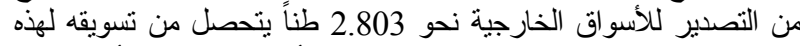

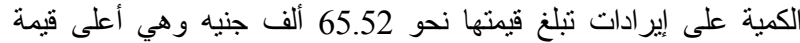

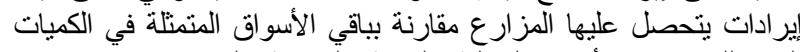

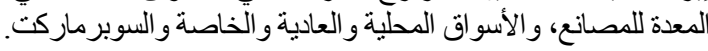

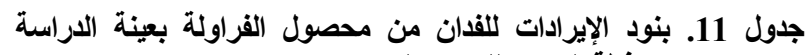

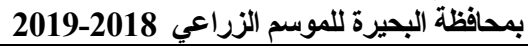

\begin{tabular}{|c|c|c|c|}
\hline القيمة بالألف جنيه & الأههية التسبية \% & الكمية بالطن & البنود ال البنا \\
\hline 30.282 & 25.7 & 5.305 & السوق المحلي \\
\hline 10.372 & 8.31 & 1.71 & الأسو اق الخاصَة \\
\hline 4.520 & 3.01 & 0.62 & السوبر ماركت \\
\hline 21.140 & 3.16 & 3.265 & الأسواق العادية \\
\hline 65.520 & 13.61 & 2.803 & الكمية المعدة للتصدير \\
\hline 47.525 & 33.41 & 6.888 & الكمية المعدة للمصانع \\
\hline 179.359 & 100 & 20.591 & الإجمالي \\
\hline 19.02 & - & 0.525 & النانج الثنأوى (محصول الثوم) \\
\hline 181.262 & - & 21.116 & الإجمالي \\
\hline
\end{tabular}

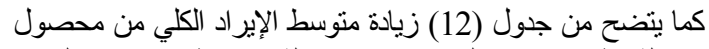

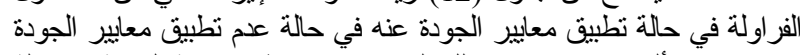

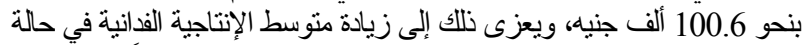

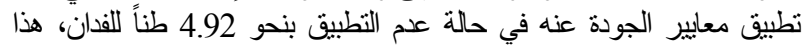

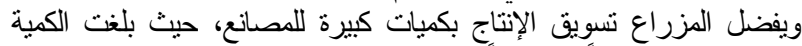

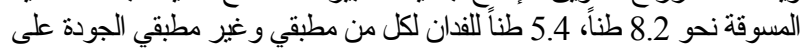

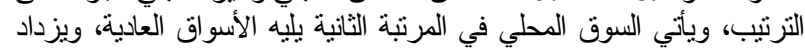

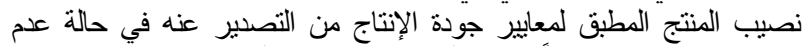

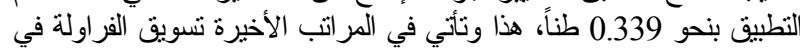

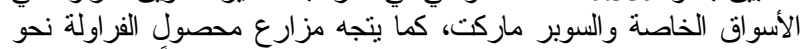

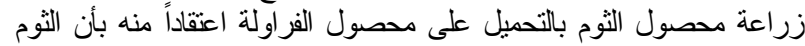
يساعده على النخلص من مشكلة النيماتودا التي بسيبها يعاني المنتج من تكبد الكثبر

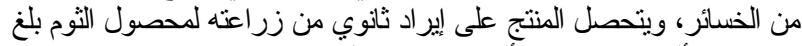

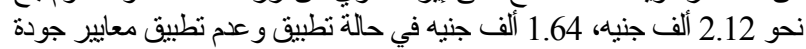
الإتتاج على التزتيب.

جدول 12. بنود الإيرادات للفدان من محصول الفراولة في حالة تطبيق وعام تطييق معايير الجودة بعينة الدراسة بححافظة البحيرة للموسم

\begin{tabular}{|c|c|c|c|c|}
\hline \multicolumn{2}{|c|}{ في مالة علدم تطبيق } & \multicolumn{2}{|c|}{ في حالة تطييق الجودة } & \multirow[t]{2}{*}{ البنود } \\
\hline لقيمة بالألف جنيه & الكمية | ل مية & القيمة بالألف جنيه & 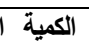 & \\
\hline 2959 & 5435 & 3087 & 5194 & الناتج الرئيسي: \\
\hline 8.41 & 1.174 & 12.04 & 2.167 & الأسو اق الخاصَّة \\
\hline 2.81 & 0.239 & 5.98 & 0.944 & 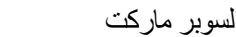 \\
\hline 17.08 & 3.109 & 24.59 & 3.398 & الأسواق العادية \\
\hline 48.16 & 2.619 & 80.31 & 2.958 & لكمبة المعدة للتصدير \\
\hline 37.36 & 5.359 & 56.17 & 8.189 & الكمية المعدة للمصانع \\
\hline 109,79 & 17.935 & 209.96 & 22.85 & 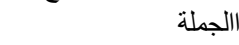 \\
\hline 1.64 & 0.489 & 2.12 & 0.556 & الناتج الثانوى (محصول الثثو. \\
\hline 111.44 & 18.424 & 212.08 & 23.406 & 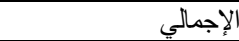 \\
\hline
\end{tabular}

تحليل الكفاوة الفنية والاقتصادية للفدان من محصول الفراولة بإستخدام

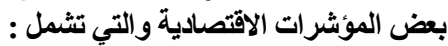

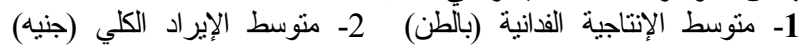

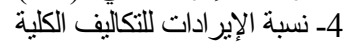

35- 5 ائد الجنيه المنتثمر ( بالقرش )

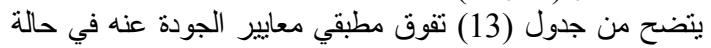

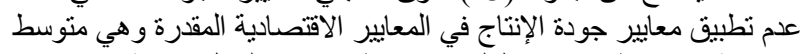

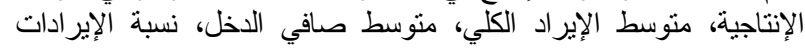

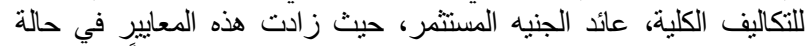
تطبيق معايير الجودة عنه في حالة عدم التطبيق بنحو 4.91 طناً، 100.64
يتضح من جدول (10) إنخفاض النكاليف الإنتاجية الفانية من محصول

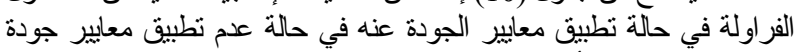

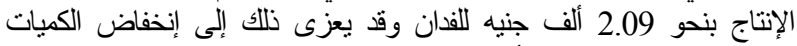

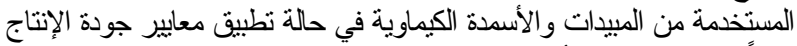

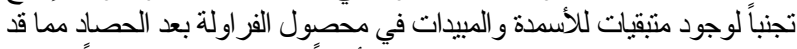

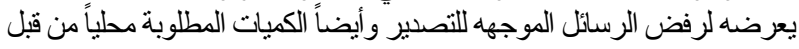
المصانع، هذا وقد ثبت عنم معنوية الفرق بين منوسط التكاليف الكلية الإتتاجية في

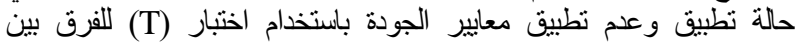

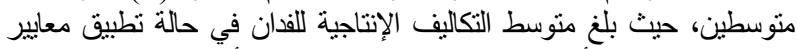

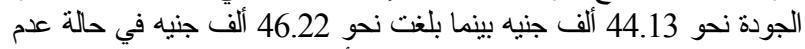
تطبيق معايير جودة الإتتاج ، وبإستعر اض الأهمية النسبية لمختلف بنود تكاليف إنتاج الفدان من الفراولة في حالة تطبيق و عدم تطبيق معايير الجودة تليين أن تكلفية

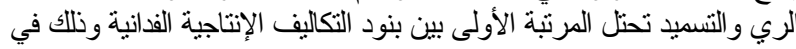

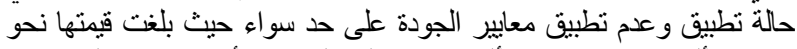

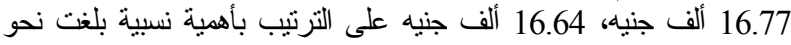
38.01\%، 36.01\% \% على الترتيب ـ وقد جاءت في المرتبة الثنانية تكلفة المكافحة

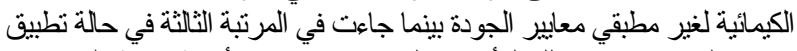

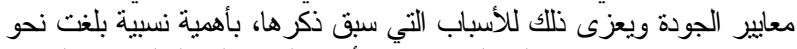

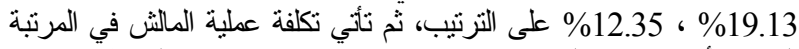

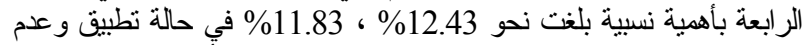

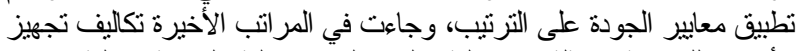

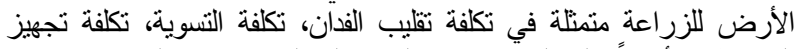

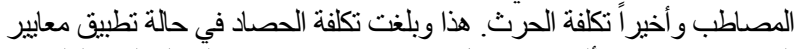

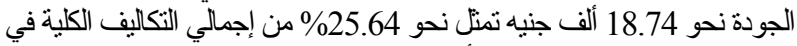

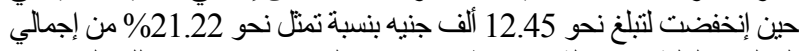

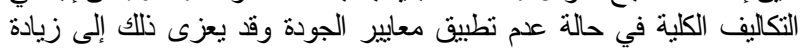

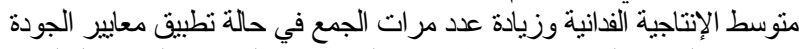

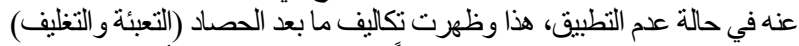

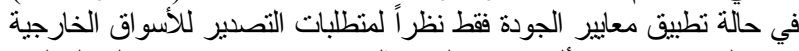

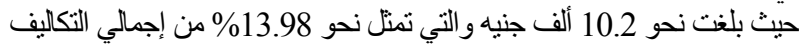
الكلية، في حين إختفى هذا البند من بنود التكاليف في حالة عدم تطبيق معايير

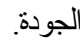

جدول 10. بنود تكاليف إنتاج وحصاد وتكاليف ما بعد الحصاد لفدان الفراولة

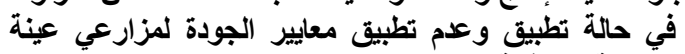

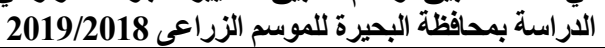

\begin{tabular}{|c|c|c|c|c|}
\hline \multicolumn{5}{|c|}{ في حلة تطييق معليير الجودة في حلة علم تطييق معليير الجودة } \\
\hline$\%$ & التكلفة بالألف جنيه & $\%$ & التكلفة بالألف جنيه & \\
\hline 1.81 & 0,836 & 1.96 & 0.866 & كلفة تجهيز الشتلات \\
\hline 6.53 & 3.017 & 6.72 & 2.968 & تقليب الفدان \\
\hline 1.49 & 0.692 & 1.91 & 0.840 & كلفة التسوية \\
\hline 0.96 & 0.442 & 0.93 & 0.411 & كلفة الحرث \\
\hline 13.17 & 6.088 & 15.78 & 6.963 & كلفة السماد البلدي \\
\hline 1.20 & 0.555 & 1.24 & 0.548 & كلفة تجهيز المصاطب \\
\hline 5.68 & 2.625 & 5.66 & 2.498 & راعة \\
\hline 36.01 & 16,646 & 38.01 & 16.775 & ي و التسمبد \\
\hline 2.19 & 1.010 & 3.01 & 1.329 & كأفحة الحيوية \\
\hline 19.13 & 8.842 & 12.35 & 5.452 & المكافحة الكيمبيائية \\
\hline 11.83 & 5.466 & 12.43 & 5.479 & فة عملية الملش \\
\hline 100 & 46.224 & 100 & 44.131 & \\
\hline$* 21.22$ & 12.453 & $* 25.64$ & 18.745 & لفة عملية الحصاد \\
\hline- & - & $* 13.98$ & 10.220 & كلفة ما بعد الحصاد \\
\hline - & 58.678 & 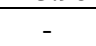 & 73.096 & جمالي \\
\hline
\end{tabular}
المصدر : جمعت وحسبث من بياتات استمارات استبيان عينة الدراسة.

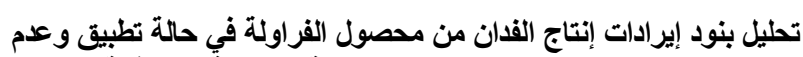
تطبيق معايير الجودة من واقع بيانات عينة الاراسة بحدافظة البحيرة لالموسم الزراعي 2018-2019.

يتضح من جدول (11) توزيع الناتج من فدان الفراولة على مختلف

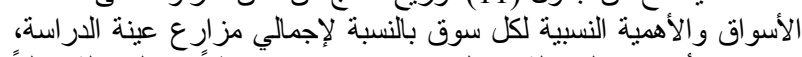

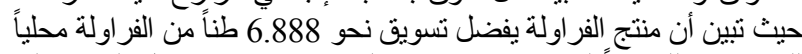

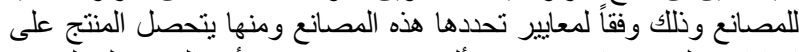

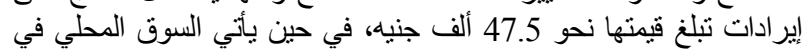




\section{Doaa H. I. Mahmoud and Fayrouz A. A. Ahmed}

النضج و لا يوجد بها عبوب، عدم وجود بصمة على الثمار وذللك وفقاً لآراء

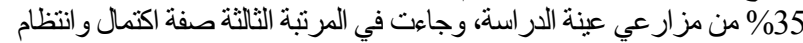

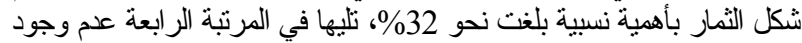

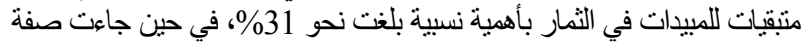

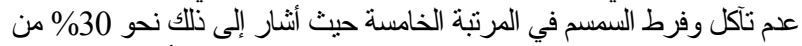

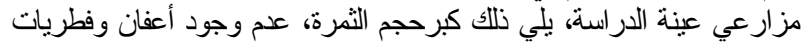

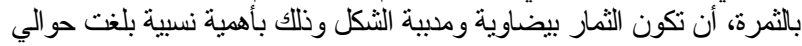

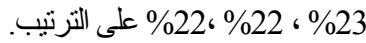

جدول 15. معايير جودة المنتج المعد للتصدير بعينة الدراسة بمحافظة البحيرة للموسم الزرعي 2018-2019.

\begin{tabular}{|c|c|c|}
\hline$\%$ & 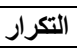 & معايير الجودة \\
\hline 46 & 46 & الثمار مكتملة اللون و الحجم \\
\hline 35 & 35 & الثمار صلبة وتتحمل عمليات ما بعد الحصاد و النقل و الثحن \\
\hline 32 & 32 & الثمار منتظمة الثنكل و الحجم \\
\hline 35 & 35 & الثمار كاملة النضج ولا يوجد بها عيوب \\
\hline 22 & 22 & الثمار بيضاوية ومدبية الثكل \\
\hline 22 & 22 & عدم وجود أعفان وفطريات \\
\hline 23 & 23 & كبر حجم الثمرة \\
\hline 35 & 35 & عدم وجود بصمة على الثمار \\
\hline 30 & 30 & عدم تآكل وفرط السمسم \\
\hline 31 & 31 & عدم وجود منتقيات للمبيدات في الثمار \\
\hline
\end{tabular}

المصدر : جمتت وحسبت من بياتات عينة الاراسة.

أهم المشاكل الإنتاجية بعينة الدراسة:

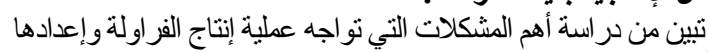

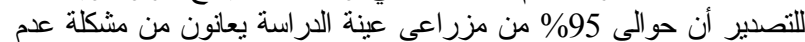

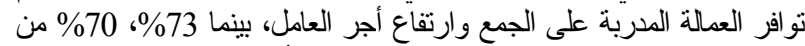

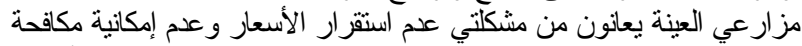

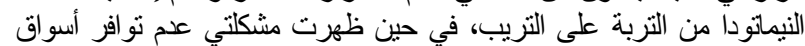

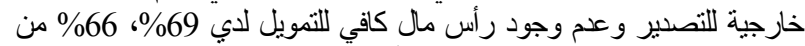

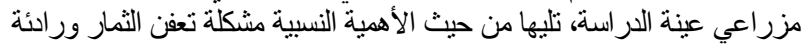

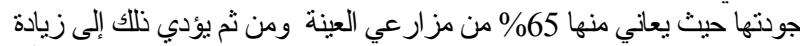

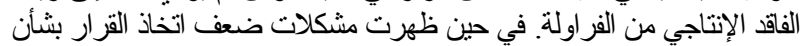

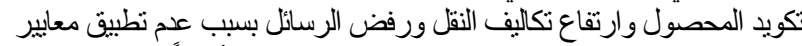

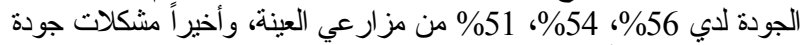

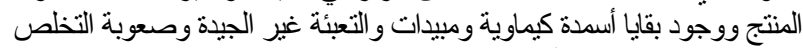

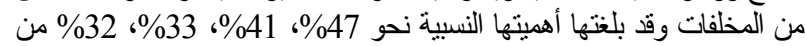
مزر اعي عينة الدراسة.

جلول 16. الأهمية النسبية لمشاكل إنتاج محصول الفراولة بعينة الدراسة

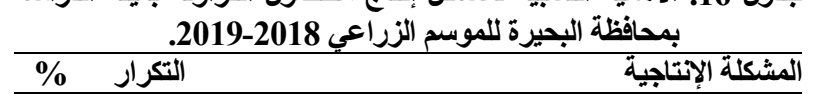

\begin{tabular}{|c|c|c|}
\hline$\%$ & التكرار & المشكلة الإنتاجية \\
\hline 95 & 95 & عدم تو افر العمالة الددربة على الجمع وإرتفاع أجر العامل \\
\hline 73 & 73 & عدم إستقرار الأسعار \\
\hline 70 & 70 & مشكلة النيماتودا \\
\hline 69 & 69 & عدم تو افر الأسواق الخارجية للتصدير \\
\hline 66 & 66 & عدم وجود ر أس مال كافي للتمويل \\
\hline 65 & 65 & ت تعفن الثمار وردائة الجودة \\
\hline 64 & 64 & زيادة الفاقد الإنتاجي \\
\hline 56 & 56 & ضعف إتخاذ القرار بشأن تكويد المحصول \\
\hline 54 & 54 & إرتفاع تكاليف النقل \\
\hline 51 & 51 & رفض الرسائل بسبب عدم تطبيق معايير الجودة \\
\hline 47 & 47 & مشكلات جودة المنتج ووجود منتج غير مرغوب فيه \\
\hline 41 & 41 & وجود بقايا أسمدة كيماوية ومبيدات كيماوية \\
\hline 33 & 33 & التعبئة غير الجيدة والعبوات غير المناسبة \\
\hline 32 & 32 & صعوبة التخلص من المخلفات \\
\hline
\end{tabular}

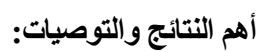

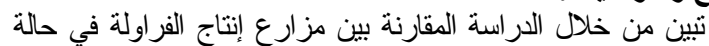
تطبيق وعدم تطبيق معايير الجودة، أن دوال الإنتاج الثمري والإنتاج لإناج ألمعلب

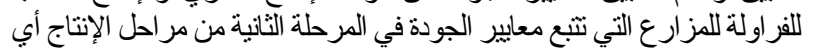

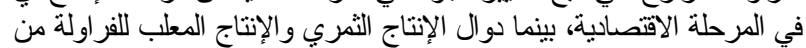

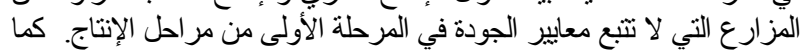

ألف جنيه، 101.68 ألف جنيه، 1.84، 1.82 قرش على الترتيب بنسبة زيادة

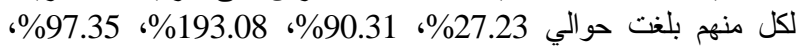
\%204.49

جدول 13. مؤشرات الكفاعة الفنية والاقتصادية لفدان الفراولة في حالة

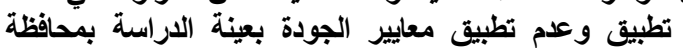

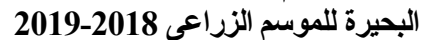

\begin{tabular}{|c|c|c|c|c|}
\hline الن الأثر & المطق & في حالة علدم تطييق & في حالة تطييق & \\
\hline 27.37 & 4.91 & 17.94 & 22.85 & بط الإنتاجية (الطن) \\
\hline 90.31 & 100.64 & 111.44 & 212.08 & راد الكلي (ألف جنيه) \\
\hline 213.97 & 46.04 & 40.21 & 126.25 & في النخل" (ألف جنيه) \\
\hline 128.46 & 1.67 & 1.30 & 2.97 & الإلإير ادات للتكاليف الكلية \\
\hline 162.5 & 0.91 & 0.56 & 1.47 & تد الجنيه المستخمر (قرش) \\
\hline
\end{tabular}

أسباب الفق من محصول الفراولة أثناء وبعد عملية الحصاد:

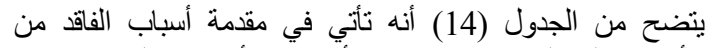

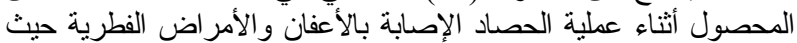

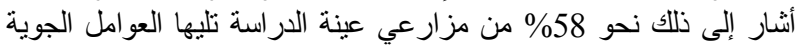

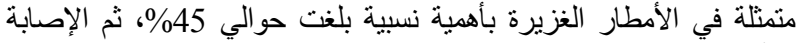

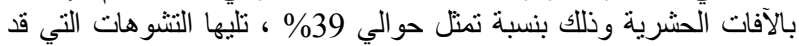

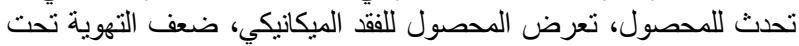

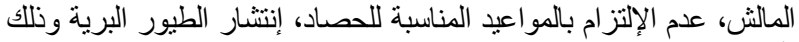

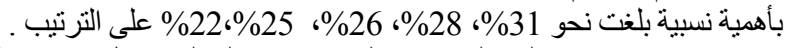
في حين جاء الفقد الميكانيكى الذي بتعرض \%

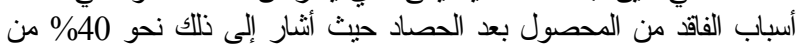

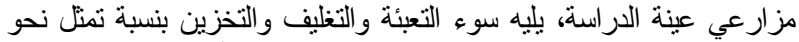

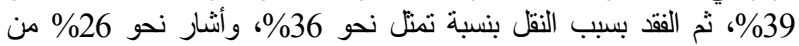

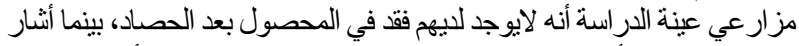

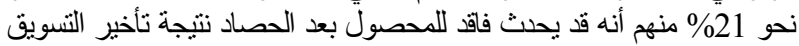

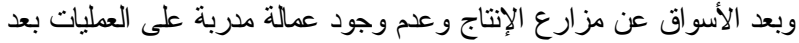
الحصاد.

جدول 14.الأهمية النسبية لأسباب الفاقد من محصول الفراولة أثناء وبعد عملية الحصاد بعينة الاراسة بمحافظة البحيرة للموسم الزئ الزراعي

.2019-2018

\begin{tabular}{|c|c|c|}
\hline$\%$ & 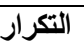 & الأسباب \\
\hline & & اء عملية الحصــاد: \\
\hline 45 & 45 & امل جوية (غزارة الأمطار) \\
\hline 58 & 58 & حسابة بالأعفان و الأمر اض الفطرية \\
\hline 39 & 39 & صاية بالآفات الحشر ية \\
\hline 31 & 31 & 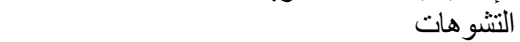 \\
\hline 28 & 28 & د الميكانيكى \\
\hline 26 & 26 & عف التهوية تحت المالش \\
\hline 25 & 25 & م الإلتز ام بالمو اعيد المناسبة للحصاد \\
\hline 22 & 22 & اليور البرية \\
\hline & & عملية الحصـاد: \\
\hline 21 & 21 & 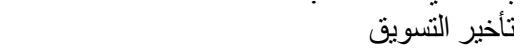 \\
\hline 25 & 25 & بل فترة التخزين \\
\hline 36 & 36 & قد نتيجة النقل \\
\hline 40 & 40 & قد الميكانيكى \\
\hline 21 & 21 & لـ الأسواق عن مزارع الإنتاج \\
\hline 39 & 39 & يء التعبئة و التغليف والتخزين \\
\hline 21 & 21 & م وجود عمالة مدربة على العمليات بعد الحصاد \\
\hline 26 & 26 & لا يوجد اند \\
\hline
\end{tabular}

يتبين من جدول (15) أن من أهم مو اصفات جودة المنتج المعد اللتصدير

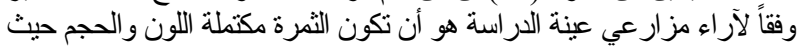

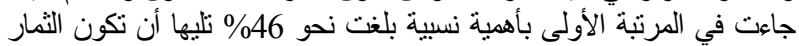

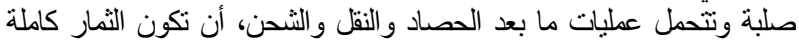




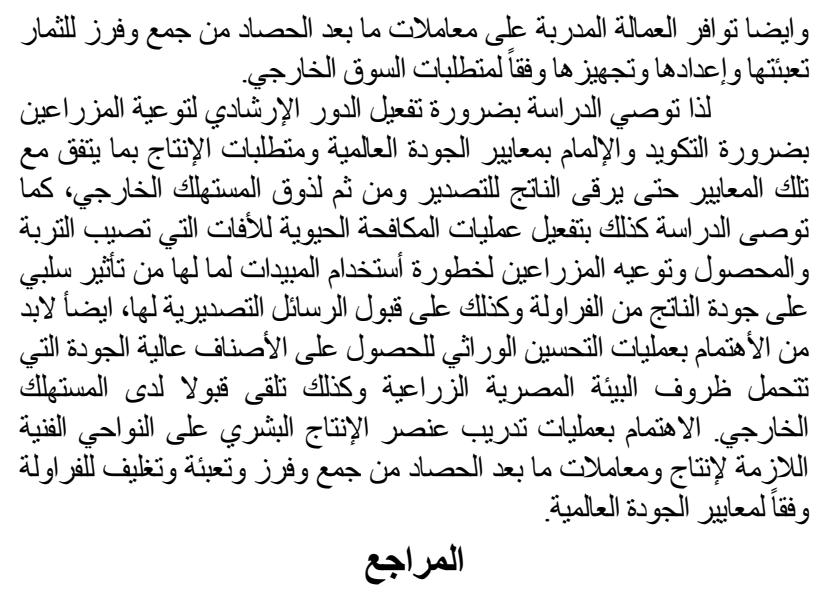

David L. Debertin. 1986. "Agricultural Production economics" second edition, Macmillan Publishing Company, a division of Macmillan Inc.
أنضح أيضاً من خلال النتائج البحثية أن عمليات خدمة الأرض وتسويتها تؤثر

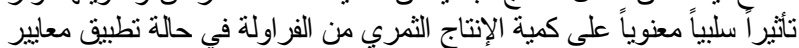

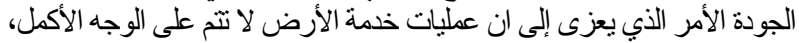

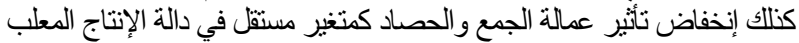

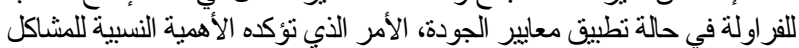

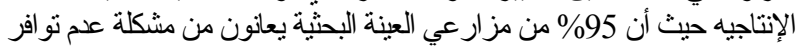

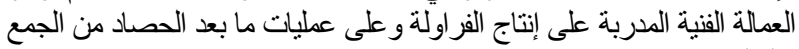

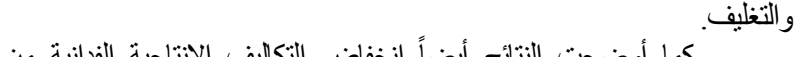

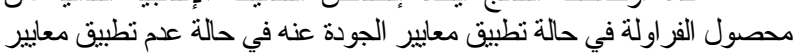

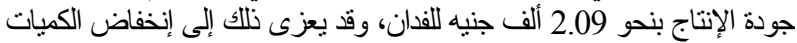

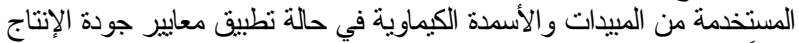

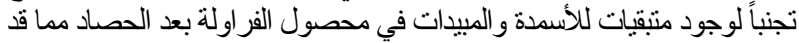

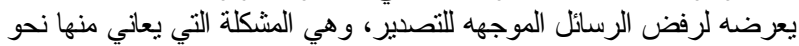

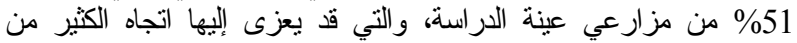

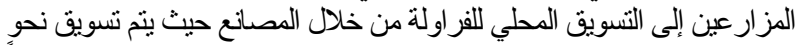

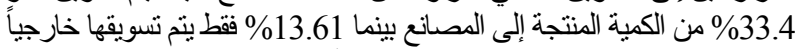

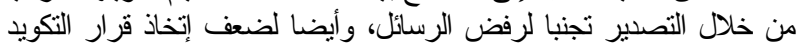

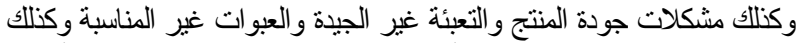

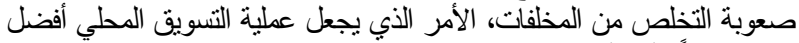

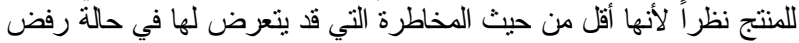

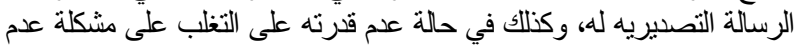

مما سبق يمكن القول بأن أهم محددات إنتاج الفراولة وفقاً لمعايير الجودة استقرار الأسعار.

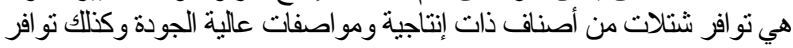

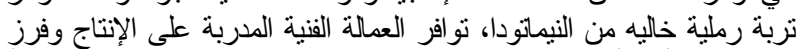
الثنتلات فرزاً جيداً قبل زر اعتها وزر اعتها بطريقة صحيحة وخدمة الأرض جيداً

\title{
Determinants of Strawberry Production in Beheira Governorate and Post-Harvest Treatments According to International Quality Standards \\ Doaa H. I. Mahmoud ${ }^{1}$ and Fayrouz A. A. Ahmed ${ }^{2}$ \\ ${ }^{1}$ Department of Economics and Agribusiness, Faculty of Agriculture, Alexand ria University \\ ${ }^{2}$ Department of Economics and Agricultural Extension and Rural Development, Faculty of Agriculture, Damanhour University
}

\begin{abstract}
The research aims to study the most important factors affecting the production of Egyptian strawberries and postharvest treatments according to international quality standards to reach the level sought by the foreign importer to meet the needs and taste of the foreign consumer. Through a comparative study between strawberry production farms in the case of the application and non-application of quality standards, through a random research sample of strawberry farmers in the province of Beheira during the agricultural season 2018-2019, it was found that the functions of fruit production and canned strawberry production of farms that follow the quality standards in the second phase of the stages Production in the economic stage, while the functions of fruit production and canned production of strawberries from farms that do not follow the quality standards in the first stage of production. The results also showed a decrease in the production costs per feddan of strawberry crop in the case of applying quality standards than in the case of non-application of production quality standards by about LE 2.09 thousand per feddan. Pesticides in the strawberry crop after harvest, which may expose him to reject messages addressed to export, a problem experienced by about $51 \%$ of the farmers of the sample of the study, which is attributed to the tendency of many farmers to local marketing of strawberries through factories where they are settled About $33.4 \%$ of the quantity produced to factories, while only $13.61 \%$ is marketed externally through export to avoid rejection of messages and also poor decision making coding as well as product quality problems improper packaging and inappropriate packaging as well as the difficulty of disposal of waste, which makes the process of local marketing better for the product It is less risky if it rejects its export message, as well as if it is unable to overcome the problem of price instability
\end{abstract}

Keywords: Strawberry Production Functions - International Strawberry Quality Standards - Post Harvest Transactions Strawberry Technical and Economic Efficiency 